\title{
ІНОЗЕМНА МОВА ЯК ОСНОВА ІНТЕГРАЦІЇ ДИСЦИПЛІН
}

\author{
Пастирська І. Я. \\ кандидат педагогічних наук, доцент, \\ дочент кафедри іноземних мов \\ Національний університет «Львівська політехніка» \\ вул. Степана Бандери, 12, Львів, Украӥна \\ orcid.org/0000-0001-5578-3397 \\ irynna.pastyrska@gmail.com
}

Ключові слова: іноземна
мова, інтегративний підхід,
мовні інтегровані курси,
предметний зміст, мовні
уміння, спеціальні дисцииліни.
У статті показано, що інтеграція як один 3 найважливіших засобів досягнення єдності повинна оптимально використовуватись у процесі навчання. Проблема цілісності знань $є$ необхідним компонентом формування змісту освіти. Інтегративний підхід до викладання дисциплін натепер переходить від узгодження змісту освіти до глибокої взаємодії, обгрунтованої інтеграції знань, умінь та елементів мислення майбутнього фахівця. Проблема інтеграції змісту дисциплін досліджувалася хоча і широко, однак доволі однобічно. Зауважено, що засвоєння учнями наявної натепер системи і сукупності знань 3 основ наук $є$ далеко не повним завданням школи.

У статті акцентовано увагу на тому, що оволодіння мовою не є головною метою, самоціллю, а лише засобом у розумінні взаємозв'язків i взаємодій мови 3 іншими дисциплінами, оскільки мовні інтегровані курси реалізовують системний підхід до збагачення всіх значущих компонентів усного i писемного мовлення на предметному змісті дисципліни, що інтегрується. Особливо ефективними є курси, в яких різноманітна мистецька діяльність використовується як методологія навчання іноземної мови і дисципліни, що інтегрується. Наголошено, що інтегративні зв'язки не ламають структуру і специфіку кожного навчального курсу, а гармонійно поєднують їх у загальну систему знань, здібностей, навичок та ціннісних орієнтацій особистості. Тоді взаємозв'язок знань та інтегративні компоненти у змісті навчання будуть органічними частинами системи реально існуючих знань та реально існуючих між ними зв'язків.

Обгрунтовано, що інтегративні зв'язки між вивченням спеціальних дисциплін та іноземної мови спрямовані на удосконалення професійних знань студентів та розвиток мовного апарату з іноземної мови.

Зроблено висновок, що за умов цілісного, інтегративного підходу до вивчення іноземної мови та спеціальних дисциплін відбувається перенесення навичок і вмінь пошуку інформації, сформованих під час навчання іноземної мови, в мовну діяльність рідною мовою. Засобами іноземної мови вдосконалюється загальна мовленнєва та предметна компетенція тих, хто навчається. 


\title{
FOREIGN LANGUAGE AS A BASIS FOR INTEGRATION OF DISCIPLINES
}

\author{
Pastyrska I. Ya. \\ Candidate of Pedagogical Sciences, Associate Professor, \\ Associate Professor at the Foreign Languages Department \\ Lviv Polytechnic National University \\ Stepan Bandera str., 12, Lviv, Ukraine \\ orcid.org/0000-0001-5578-3397 \\ irynna.pastyrska@gmail.com
}

Key words: foreign language, integrative approach, integrated language courses, subject content, language skills, special disciplines.

\begin{abstract}
The article shows that integration as one of the most important means of achieving unity should be optimally used in the learning process. The problem of knowledge integrity is a necessary component of the formation of the content of education. An integrative approach to teaching disciplines today goes from harmonizing the content of education to deep interaction, sound integration of knowledge, skills and thinking elements of the future specialist. The problem of integration of the content of disciplines was studied though widely, but rather one-sidedly. It is noted that the assimilation by students of the current system and the set of knowledge on the basics of science is not a complete task.

The article emphasizes that language acquisition is not the main goal, an end in itself, but only a means of understanding the relationships and interactions of language with other disciplines, as integrated language courses implement a systematic approach to enriching all important components of oral and written speech basing on the content of the discipline that is integrated. Particularly effective are courses in which a variety of artistic activities are used as a methodology for teaching a foreign language as an integrated discipline.

It is emphasized that integrative connections do not break the structure and specifics of each course, but harmoniously combine them into a common system of knowledge, abilities, skills and values of the individual. Then the relationship of knowledge and integrative components in the content of learning will be organic parts of the system of real knowledge and the real connections between them.

It is substantiated that the integrative connections between the study of special disciplines and foreign language are aimed at improving the professional knowledge of students and the development of the language apparatus in a foreign language.

It is concluded that under the conditions of a holistic, integrative approach to the study of a foreign language and special disciplines, the skills and abilities of searching for information formed during the study of a foreign language are transferred to the language activity in the native language.

The general speech and subject competence of learners is improved by means of a foreign language.
\end{abstract}

Постановка проблеми. У зв'язку зі змінами, що відбувалися у науці і освіті, проблема інтеграції змісту освіти була порушена в другій половині $\mathrm{XX}$ століття, коли активно розглядалися питання узагальнення і систематизації знань, міжпредметних зв'язків, формування світогляду. Значний потенціал інтеграції в педагогіці підтверджується науковими розробками щодо інтеграції окремих предметів, методик, технологій. У психолого-педагогічній літературі досліджувалися питання організації навчання студентів із застосуванням принципу інтеграції (А. Беляєва, М. Берулава, С. Гончаренко, А. Данилюк, С. Клепко, І. Козловська, І. Сіняговська та ін.). Т. Шаргун, І. Ключковська, Т. Станівська, Ю. Стиркіна та ін. аналізували застосування інтегративного підходу під час вивчення іноземних мов у закладах вищої освіти.

Мета статті - показати, що інтегративний підхід до викладання дисциплін натепер переходить від узгодження змісту освіти до глибокої взаємодії, обгрунтованої інтеграції знань, умінь та елементів мислення майбутнього фахівця. 
Оволодіння мовою не є головною метою, самоціллю, а лише засобом у розумінні взаємозв' язків і взаємодій мови з іншими дисциплінами, оскільки мовні інтегровані курси реалізовують системний підхід до збагачення всіх значущих компонентів усного і писемного мовлення на предметному змісті дисципліни, що інтегрується.

Виклад основного матеріалу дослідження. Зростання важливості інтегративних рухів в освіті породжує низку суперечностей між можливостями використання позитивного історичного досвіду інтеграції за сучасних умов та недостатнім рівнем його реалізації на практиці. Натепер є потреба цілісного аналізу взаємодії змісту гуманітарних і природничих дисциплін, але наявна іiі фрагментарність у педагогічних дослідженнях. Необхідно періодизувати інтеграційні процеси у вітчизняній педагогічній науці, оскільки рівень виявлення інтегративних тенденцій на різних етапах досліджуваного періоду $є$ недостатнім. А обгрунтування інтеграції змісту гуманітарних та природничих дисциплін як проблеми загальнопедагогічного масштабу зумовлюється ії малопомітним місцем у реальній практиці сучасної освіти.

Розглянемо приклад іноземної мови як основи інтеграції змісту природничих та гуманітарних дисциплін.

Взаємозв'язок іноземної мови 3 предметами гуманітарного циклу зумовлюється тим, що функції іноземної мови як шкільного предмета полягають у розвитку мовленнєвої діяльності учня, у здібності використовувати мову як засіб спілкування й залучення до іншої культури. Наприклад, інтегрований курс «Навколишній світ» (1-3, 1-4 класи) ставить за мету навчити учнів: правильної поведінки вдома, у школі, на вулицях міста, допомагати одне одному. Комунікативні завдання з мови на цьому періоді навчання пов'язані $з$ предметними діями. Учні повинні оволодіти формами знайомства, вітання, вибачення, прощання, запрошення, поздоровлення, розповіді, розмови, опису, прохання, подяки, пропозиції, відмови, погодження англійською мовою. Цілком природним $є$ створення інтегрованих курсів іноземної мови з іншими дисциплінами, отже, за допомогою мови можна отримувати знання 3 історії, літератури, техніки, природознавства, мистецтва. «Мова набуває свого природного статусу своєрідного «провідника» інформації. Інтегруючи іноземну мову з іншими предметами, ми реалізуємо всі функції спілкування на предметному змісті, на основі діяльності» [1, с. 106].

Лінгвокраїнознавчий аспект навчання - це самостійний аспект навчання іноземної мови (поряд 3 фонетичним, лексичним, граматичним та стилістичним), який відбиває національно-культурний компонент та естетичний зміст і форму мовного матеріалу. Кінцевою метою засвоєння цього аспекту виховання естетичного смаку є формування у студентів цілісної системи уявлень про основні культурні традиції, звичаї та реалії країни, мова якої вивчається, їх естетичне наповнення, що дозволяє студентам зрозуміти світогляд носіїв мови, поповнити власний соціально-культурний та естетичний досвід особистості, формує в неї позитивну мотивацію та чуттєве переживання освоєння мовної інформації, виховує звичку та внутрішню потребу в оволодінні, вдосконаленні та реалізації набутих мовних умінь. Різноманітність національних особливостей, які втілені в реаліях, $є$ основою та об'єктом лінгвокраїнознавства, за допомогою якого ми вивчаємо і намагаємось зрозуміти внутрішній устрій, економічний та культурний рівень, історію країни, мова якої вивчається, іiі героїв, традиції та звичаї. Саме через реалії ми вивчаємо певні риси, особливості характеру, притаманні саме цій країні, яка існує в певну історичну епоху, тому що лексика реагує на всі зміни суспільного життя, і це відображено в словниковому запасі країни.

На відміну від традиційних програм, які пропонують отримання моносистемних знань іноземної мови (види мовленнєвої діяльності + граматика), інтегровані іншомовні програми формують полісистемні знання мови. Особливо цінним $є$ те, що у таких програмах оволодіння мовою не є головною метою, самоціллю, а лише засобом у розумінні взаємозв'язків і взаємодій мови з іншими дисциплінами. По суті, мовні інтегровані курси реалізовують системний підхід до збагачення всіх значущих компонентів усного і писемного мовлення на предметному змісті дисципліни, що інтегрується. Особливо ефективними є курси, в яких різноманітна мистецька діяльність використовується як методологія навчання іноземної мови i дисципліни, що інтегрується. Серед різноманіття інтегрованих курсів мовні інтегровані курси найменш досліджені, тому варто розглянути зміст і технології викладання мовних інтегрованих курсів у світовому педагогічному просторі. Наявні інші спроби створення мовних інтегрованих курсів, зокрема новий підхід до розуміння творчості Шекспіра, де береться за основу принцип доповнюваності Нільса Бора. Проєктуючи фізичний принцип на світосприймання Шекспіра, визначають його як спосіб бачення, за якого протилежні уявлення про сенс життя співіснують у гармонічному поєднанні. «Саме фізика з ії розумінням взаємозалежності між суб'єктом і об'єктом, протиріччям і парадоксом допомогла проаналізувати принципи естетики Шекспіра, розглянути конфлікти по-новому і запропонувала новий метод вирішення складних проблем сучасності, нові засоби літературного аналізу» [1, с. 13]. 
Прикладом інтегрування англійської мови 3 екологічною проблематикою може бути курс російської вчительки Л. Зені [2]. Засобами іноземної мови вдосконалюється загальна мовленнєва компетенція учнів з екологічних проблем, впроваджується гуманістичне виховання, активізується гармонічний розвиток дитини. Крім того, виникають умови для сприятливого розвитку суспільного мислення, для підвищення активної боротьби за здоров'я країни й світу, формується емоційно-ціннісне ставлення до природи, забезпечується участь учнів у конкретних природоохоронних акціях.

Характеризуючи лінгвомистецькі інтегровані курси, Ю. Стиркіна [1] підкреслює, що у множині інтегрованих курсів вони посідають особливе місце. Мистецтво в них використовується у подвійній якості: об'єкта (дисципліна, що інтегрується 3 мовою, змістовий компонент) і засобу (операційний компонент, методологія) навчання. У дослідженні під лінгвомистецькими інтегрованими курсами ми розуміємо систему збагачення всіх значущих компонентів усного і писемного мовлення на предметному змісті філологічних i мистецьких дисциплін (музика, драма, література, малювання, ритміка тощо). Інтеграція іноземної мови 3 мистецтвом реалізує певний ступінь інтеграції в інтегральній системі, оскільки він має всі три компоненти: елементи інтеграції (мова й мистецтво як засоби пізнання світу); підстава інтеграції (принципи інтегрування іноземної мови з мистецтвом); зінтегрований об'єкт (цілісний, новий результат інтегрованого навчання).

За умов цілісного, інтегративного підходу до вивчення іноземної мови та спеціальних дисциплін відбувається перенесення навичок і вмінь пошуку інформації, сформованих під час навчання іноземної мови, в мовну діяльність рідною мовою. Наприклад, навчання читання іноземною мовою сприяє розвитку у студентів навичок, передбачених освітньо-кваліфікаційними характеристиками: професійно значущі для інженера дії та операції - аналіз, синтез, зіставлення, прогнозування, відновлення цілого за його складниками, висунення і захист гіпотез тощо, органічно входить у процес читання, процесуальна сторона якого має аналітично-синтетичний характер і потребує застосування всіх цих операцій. Ці дії, загальні для творчої діяльності в будь-якій галузі, широко використовуються у подальшому застосуванні набутої під час читання інформації. Встановлення інтеграційних зв'язків доцільне не лише стосовно фактичної інформації, але виконуваних дій та операцій. У цьому разі іноземна мова здатна впливати на формування необхідних інженеру низки професійних умінь, тобто у процесі підготовки фахівців у вищих навчальних закладах інтеграція змісту спеціальних дисциплін зі знаннями іноземної мови допомагає виділяти і презентувати професійно значущі знання, створювати та розвивати комунікаційні уміння тощо.

Як зазначає Т. Шаргун, іншомовна підготовка у вищих технічних навчальних закладах сприяє «передусім формуванню особистості, здатної до співіснування з представниками інших мов і культур, яка прагне до саморозвитку і самореалізації, підвищення рівня освіченості й розширення кругозору, 3 розвиненими комунікативними навичками, що дозволяють їй вільно спілкуватися 3 партнерами 3 інших країн» [3, с. 166]. Водночас міжпредметна основа тематичного змісту сфер спілкування навчального предмета «Іноземна мова» забезпечує створення навчального середовища для втілення принципу інтегративності. Прикладом інтеграції технічних та лінгвістичних знань студентів $\epsilon$ інтеграція на лексичному рівні. Під час вивчення спеціальних дисциплін студенти постійно зустрічаються зі словами іноземного походження, термінами, величинами, назвами одиниць тощо. Тому інтегративні зв'язки між вивченням спеціальних дисциплін та іноземної мови спрямовані на удосконалення професійних знань студентів та розвиток мовного апарату з іноземної мови.

Саме інтегративні чинники спроможні регулювати співвідношення різнорідних знань та забезпечити їх сумісність, повноту змісту, професійне спрямування навчального матеріалу.

До основних напрямів, які забезпечують ці зв'язки, можна віднести такі: розкриття значень технічних термінів, розуміння основних способів словотворення, обгрунтування складних морфем та термінологічних скорочень, обгрунтування позначень термінів та одиниць, правильну вимову та наголос, переклад складних слів та словоскорочень на основі їх частин тощо. Доцільно дати загальне поняття про аналіз слова: в основному семантичний, оскільки розуміння значення слова допомагає його запам'ятовуванню та правильному використанню. Зокрема, це широковживані іншомовні слова, такі як: generator - творець, inductio - збуджувач, baros - важкий, hydros вологий, mikros - малий, thermo - теплий тощо. Розуміння значення ряду суфіксів та префіксів у словах іншомовного походження допомагають студентам встановити, про яке саме поняття чи пристрій ідеться. Зокрема, це такі префікси, як «авто-», «аеро-», «гео-», «гідро-», «електро-», «моно-», «полі-» тощо.

Розуміння значення суфікса у слові іншомовного походження дає можливість усунути плутанину у термінах. Наприклад, спектроскоп - пристрій для спостереження, спектрограф-пристрійдлязаписурезультатівспостереження, 
спектрометр - вимірювальний пристрій. Суттєву роль для вільного користування позначеннями має розкриття значення іншомовних слів, від яких походять ці величини: сила (forse - F), енергія (energy - E), об'єм (volume - V), швидкість (velocity - v), прискорення (acceleratio - a) тощо.

Значні можливості інтеграції мають і спеціальні дисципліни, хоча їх реалізація вимагає тісної співпраці викладачів обох предметів. Одним 3 найефективніших способів оволодіння навичками читання спеціальної літератури може бути використання коротких іншомовних резюме до кожної теми. Ефективність такого методу дуже висока: не витрачаючи практично часу, студенти записують невелике резюме, співставляють значення слів, бачать які терміни співпадають, які різняться. Такі резюме протягом усього часу навчання становлять не значний за обсягом, але інформативно місткий іншомовний текст.

Перевага описаного методу є дуже суттєвою: якщо в процесі вивчення іноземної мови студенти засвоюють окремі фрагментарні професійно спрямовані тексти, то у цьому разі формується змістова інтегративна система, яка охоплює увесь навчальний матеріал з певної фахової дисципліни (чи дисциплін). Саме така системність і є головною ознакою інтегративності зв'язків іноземної мови та спеціальних дисциплін, а не просто професійної спрямованості окремого іншомовного тексту чи традиційних міжпредметних зв'язків.

Низка вчених присвятила свої праці дослідженню інтегративних форм і методів навчання. Зокрема, обгрунтовано інтеграцію традиційних і інноваційних методів навчання іноземної мові у формуванні навичок студентів. Стосовно вивчення іноземних мов має місце плюралізм методів викладання іноземних мов, що дає можливість застосовувати всі види технічних засобів навчання, в тому числі і комп'ютерні електронні курси. Варто підкреслити, що інтегровані методи навчання потребують і великих затрат часу.

Наукове обгрунтування інтегративного підходу до методів навчання у професійній підготовці фахівців передбачає забезпечення таких вимог: обгрунтування педагогічних умов інтеграції методів професійно орієнтованих, фундаментальних та гуманітарних дисциплін у підготовці фахівця; виявленні особливостей інтеграції методів навчання у професійній підготовці фахівців конкретного профілю; формуванні системи методів навчання на основі інтегративного підходу до вивчення різноциклових дисциплін; розробці моделі інтеграції методів навчання різноциклових дисциплін у підготовці фахівця конкретного профілю [4]. Таким чином, можна зробити висновок, що проблема інтеграції іноземних мов та спеціальних дисциплін активно досліджується в укра- їнській професійній педагогіці протягом останніх років. Однак ці дослідження потребують наукової оцінки та узагальнення.

Проблема інтеграції повинна вирішуватися не лише на емпіричному рівні, а й базуватися на глибоких теоретичних засадах. Однак на практиці часто виводяться спочатку дидактичні еквіваленти наук та елементів знань про певні технології, складаються навчальні програми, а тоді наводяться міжпредметні зв’язки. Вибір же предметної системи знань та необхідних інтегративних комплексів знань, як правило, базується на застарілих класифікаціях галузей знань, які неспроможні відповідно реагувати на зміни у науці та виробництві. Тому такі осучаснення програм часто лише ускладнюють зміст навчання. Аналіз розробок 3 проблеми міжпредметних зв'язків та професійної спрямованості загальноосвітніх знань у професійній школі доводить принципову неможливість побудови дидактичної теорії знизу, тобто шляхом методичного удосконалення традиційних форм та змісту навчання. За цієї можливості міжпредметні зв'язки підтягуються до вирішення складної та неоднозначної проблеми взаємодії знань. Будучи обмеженими за своєю природою (взаємообмін інформацією між окремими галузями знань), міжпредметні зв'язки на певній стадії вичерпують свої можливості. Тоді їх впровадження стає неефективним і формальним. Теоретичні та практичні розробки 3 профілювання знань та міжпредметні зв'язки $\epsilon$ цінним набутком як дидактики, так і окремих методик. Разом із тим основи теорії міжпредметних зв'язків у жодному разі не можуть бути трансформовані в положення теорії інтеграції шляхом окремих доповнень, розширень чи екстраполяцій. Теорія інтеграції є якісно новим утворенням, що органічно включає у себе теорію міжпредметних зв'язків та принцип професійної спрямованості навчання як частинні випадки.

Усі наявні в науці особливості повинні так чи інакше знайти своє відображення у навчальному процесі. Різні позначення тих же величин на уроках суміжних предметів та різне трактування споріднених понять у рамках природничих дисциплін значно ускладнюють процес навчання, ведуть до зайвих затрат часу i перевантаження учнів, якщо цей час можна ефективно використати для розумового розвитку та формування творчих здібностей учнів. У навчальному процесі повинна відображатися і універсалізація понять. Саме інтеграція знань і умінь спроможна забезпечити єдиний підхід до пізнавальних прийомів під час вивчення суміжних дисциплін, а також відобразити ефективність використання різних підходів до одного i того ж явища. 
Висновки. Загальна суперечність між рівнем сучасних вимог до здобувачів освіти та реальною практикою навчання загальноосвітніх та спеціальних дисциплін зумовлює загострення суперечностей між інтегративним змістом фахової підготовки і фактологічним характером змісту освіти, зростанням обсягу знань і недосконалістю засобів їх згортання й архівації, проблемним принципом структурування сучасної науки та предметним підходом до конструювання змісту освіти. Інтеграція знань дає можливість розв'язати низку практичних проблем в освіті, розробити інноваційні критерії відбору змісту навчального матері- алу, реалізувати систематизацію знань студентів на рівні навчально-пізнавального процесу загалом. Іноземна мова виступає як основа інтеграції змісту природничих та гуманітарних дисциплін.

Засобами мовних інтегрованих курсів реалізовується системний підхід до обгрунтованої інтеграції знань, умінь та елементів мислення майбутнього фахівця, оскільки відбувається взаємозв'язок іноземної мови як основи інтеграції з предметами різних циклів. Засобами іноземної мови вдосконалюється загальна мовленнєва та предметна компетенція тих, хто навчається.

\section{ЛІТЕРАТУРА}

1. Стиркіна Ю.С. Дидактичні засади підготовки майбутніх учителів іноземної мови до викладання інтегрованих курсів : дис. ... канд. пед. наук : 13.00.04. Полтава, 2001. 240 с.

2. Зеня Л.Я. Воспитание экологической культуры школьников средствами иностранного языка. Иностранный язык в школе. 1990. № 4. С. 30-34.

3. Шаргун Т.О. Інтеграція знань студентів зі спеціальних дисциплін та іноземних мов у технічних університетах. Проблеми освіти. 2004. № 39. С. 165-171.

4. Білик О.С. Педагогічні умови інтеграції методів навчання фахових дисциплін майбутніх будівельників у вищих технічних навчальних закладах : дис. ... канд. пед. наук : 13.00.04. Вінниця, 2009. $214 \mathrm{c}$.

5. Гончаренко С.У., Козловська І.М. Теоретичні основи дидактичної інтеграції у професійній середній школі. Педагогіка і психологія. 1997. № 2. С. 9-18.

\section{REFERENCES}

1. Styrkina, Y.S. (2001). Dydaktychni zasady pidhotovky maybutnikh uchyteliv inozemnoyi movy do vykladannya intehrovanykh kursiv [Didactic principles of training future teachers of a foreign language to teach integrated courses] (PhD Thesis), Poltava : Poltava National Pedagogical University [in Ukrainian].

2. Zenya, L.Ya. (1990). Vospytanye ékolohycheskoy kul'tury shkol'nykov sredstvamy ynostrannoho yazyka [Education of ecological culture of schoolchildren by means of a foreign language]. Ynostrannyy yazyk $v$ shkole. No. 4. S. 30-34 [in Russian].

3. Sharhun, T.O. (2004). Intehratsiya znan' studentiv zi spetsial'nykh dystsyplin ta inozemnykh mov u tekhnichnykh universytetakh [Integration of students' knowledge of special disciplines and foreign languages in technical universities]. Problemy osvity. No. 39. S. 165-171 [in Ukrainian].

4. Bilyk, O.S. (2009). Pedahohichni umovy intehratsiyi metodiv navchannya fakhovykh dystsyplin maybutnikh budivel'nykiv u vyshchykh tekhnichnykh navchal'nykh zakladakh [Pedagogical conditions of integration of methods of teaching professional disciplines of future builders in higher technical educational institutions] (PhD Thesis). Vinnytsia : Vinnytsia State Pedagogical University of Mykhailo Kotsiubynskyi [in Ukrainian].

5. Honcharenko, S.U., Kozlovska, I.M. (1997). Teoretychni osnovy dydaktychnoyi intehratsiyi u profesiyniy seredniy shkoli [Theoretical foundations of didactic integration in vocational high school]. Pedahohika $i$ psykholohiya. No. 2. S. 9-18 [in Ukrainian]. 